\title{
Inventing Oncomice: making natural animal, research tool and invention cohere
}

\author{
ROSEMARY ROBINS ${ }^{1}$
}

\begin{abstract}
This paper examines how the oncomouse became a patentable invention. The oncomouse began life in the laboratory, where it was genetically modified for use as a research tool to assist with the study of human cancer. Its design, a product of genetic modification, made the oncomouse potentially patentable subject matter. The United States was the first jurisdiction to award the patent and several others followed. However, the question of animal patenting was most contentious in Europe and Canada. In this paper I examine debates about animal patenting within the legal and moral spaces created by United States, European and Canadian patent law, focusing on differences that emerged in each case. I argue that oncomouse as a patentable invention was made possible and acceptable as different ways of being mouse as natural animal, research tool and invention were made to cohere: that is as they were made to overlap and depend upon one another. In the paper I use the term "cohere" to describe the logic of animal patenting that emerged with, and was essential to, the outcome in each jurisdiction. I describe an ontological politics of connecting and separating different ways of being mouse, as the oncomouse's genetic modification, risks, benefits, and suffering were juxtaposed with patent law, precedent, laboratory protocols, and understandings of human agency and control. As connections and separations were made, a relation, "natural animal-research tool-invention", was established, and logic of animal patenting emerged: but differently each case.
\end{abstract}

\section{Introduction}

Now the opportunity to patent an object, and in this case animals, then creates an environment in which someone can hope to obtain a financial return if they choose to invest in that process... That's our system. You may like it - you may not like it. (Philip Leder) ${ }^{2}$

The patenting of animals is out of step with both religious and modern secular beliefs. From a religious viewpoint it is offensive, even blasphemous, for humanity to claim to have "invented" an animal; it is God, not humanity, who creates life. From a secular viewpoint an increasing number of people view animals not as existing simply for our use and profit, but as our fellow creatures capable like us of feeling pain and suffering. (British Union for the Abolition of Vivisection) ${ }^{3}$

These statements are responses to the patenting of the Oncomouse, a genetically modified mouse that was the first animal to be patented. The Oncomouse began its life in a laboratory where it was set to work as a research tool to assist with the study of cancer. What made this mouse different from its laboratory rodent brothers and sisters before it was its design, or more specifically the means by which it was 
designed, that enabled it to become patent-eligible subject matter. As the quotes above suggest, the patentability of this animal generated a debate about the relationship between human and non-human animals: what is appropriate, moral, right and good.

The first jurisdiction to allow the patent was the United States, and several others followed. However, the matter was most contentious in Europe and Canada, where various groups, committees and courts of law debated the acceptability of patenting the oncomouse over a twenty-year period. In each case, there was opposition to animal patenting based on moral concerns, but the extent to which such concerns were able to influence the outcome differed and was contingent upon interpretations of patent legislation in each jurisdiction. The United States awarded the patent in full; in Europe it was awarded in a modified form; and Canada remains the only jurisdiction in the world to have rejected animal patenting. It is these differences that make a comparative analysis of the United States, European and Canadian debates so compelling.

In my analysis I focus on the connections and separations made between mouse as natural animal, research tool and invention, as interpretations of patent legislation were made by patent officers and courts of law within the legal and moral spaces created by the United States Patent and Trademarks Office, the European Patent Office and the Canadian Patent Office. I argue that oncomouse as a patentable invention is achieved and acceptable when mouse as natural animal, research tool and invention overlap and depend upon one another: that is when they cohere. ${ }^{4} \mathrm{I}$ am using John Law's conceptualisation of "coherence" 5 to describe the logic of animal patenting that emerges with, and is essential to, the outcome in each case. Law uses the concept of "coherence" to describe an understanding of how objects can be simultaneously singular and multiple. The singularity of an object, in this case the oncomouse as patentable invention, is contingent upon multiple enactments of that object, in this case as natural animal, research tool and invention, that intersect, overlap and depend upon one another - that cohere. Law describes this way of writing about objects as a "fractional knowing" that does not efface the object's multiplicity. ${ }^{6}$ Law's work extends that of scholars in Science and Technology Studies (STS) who, using actor-network theory as the starting point, have explored the explanatory potential of an empirical metaphysics ${ }^{7}$, multiplicity ${ }^{8}$, ontological politics ${ }^{9}$, and ontics $^{10}$. These scholars hold that people and things, humans and non-humans, are contingently made to belong to the real within networks of relations that are fluid and emergent. These networks are formed as the practices and negotiations of science, law, policy, and public debate link certain things together and keep other things apart. This approach is an empirical undertaking that addresses how things, such as an animal as an invention, come to occupy the attention of scientists, patent officers, courts of law, and citizens, and how they either persist or pass away as objects of enquiry and interest. This approach emphasises the material and intellectual culture and work that is needed to bring objects of science, and in this case objects of patent protection, into being as entities that belong to the real. ${ }^{11}$

The contingency of being oncomouse has been beautifully espoused in Haraway's analysis of OncoMouse ${ }^{\mathrm{TM}}{ }^{12}$, the commercial entity sold under licence by Du Pont. 
For Haraway, OncoMouse ${ }^{\mathrm{TM}}$ is kin, a mouse that suffers so that we may live, and is born into the "matrices" of "The New World Order". ${ }^{13}$ This New World Order announces itself with the products of corporate biology, among which OncoMouse ${ }^{\mathrm{TM}}$ is an example par excellence, by being the first patented animal in the world. In Haraway's account, the oncomouse is a material and semiotic entity, a hybrid of nature, laboratory and corporate worlds that makes make technical, financial and semiotic sense. ${ }^{14}$

Like Haraway, I am interested in the contingency of being oncomouse but I focus specifically on negotiations about the patentability of this mouse, and on the links and separations that are made between mouse as natural animal, research tool and invention. I examine how the oncomouse's genetic modification, risks, benefits, and suffering are juxtaposed with patent law, precedent, laboratory protocols, and understandings of human agency and control to produce the relation "natural animalresearch tool-invention" upon which the patenting of the oncomouse depends. In the discussion that follows, I draw upon two interviews with the one of the mouse's inventors, scientific papers, patent applications, and transcripts of patent disputes. I begin with mouse as research tool and examine the connections and separations made that enabled mouse as natural animal and mouse as research tool to cohere. I then examine the patenting of the oncomouse in the United States, Europe and Canada, paying particular attention to the connections and separations made between suffering, risks, benefits, patent law, and moral concerns. I conclude by considering what is gained by examining the patenting of the oncomouse in this way. I suggest that the analysis I develop in this paper enables a form of transparency not otherwise possible because it reminds us that our reality - our way of moving forward - is not given in the order of things but made (chosen), and that it could have been otherwise.

\section{Oncomouse as research tool}

The Oncomouse began its life at Harvard Medical School in the laboratory of Philip Leder and his colleagues who were interested in the role and function of oncogenes ${ }^{15}$ in the formation of cancer. This research evolved from Leder's earlier work into the cause of a particular cancer called Burkitt lymphoma. Leder found in this case that one of the genes that controlled growth in malignant cells, a $c$-myc gene, had been moved from its normal chromosomal location, and in the process had become activated as an oncogene. Leder and his colleagues hypothesised that the activation of this oncogene had something to do with its translocation and was activated through a regulatory rather than coding disturbance. They set out to test this hypothesis using transgenic mice. ${ }^{16}$

We wanted to take the same genes, more-or-less, the myc gene which was involved in Birkitt lymphoma, and we wanted to introduce it into a mouse to ask if it could be responsible for the formation of additional malignancies. So really the precise purpose of that work was to demonstrate that c-myc was able to act as an oncogene within the context of an animal. 
Making transgenic animals requires skill, and Leder had tried and failed to do this in the past. ${ }^{18}$ However, at Harvard Medical School Leder was fortunate to have a postdoctoral fellow, Tim Stewart, who "in addition to having a wonderful brain had good hands as well" and was able to micro-manipulate mouse oocytes and introduce DNA into them under conditions that were "exacting and demanding". ${ }^{19}$ The mouse was modified using recombinant DNA techniques ${ }^{20}$ to become a model for human disease that allowed Leder and his colleagues to study cancer causing oncogenes by extrapolating from the mouse to the human. "So we just sort of used them interchangeably".21

It was tough going, and in my interview with him, Leder described the mixture of excitement and fear with which they greeted the first of their transgenic mice to develop a tumor.

So when Tim brought up the first mouse and showed it to us it was an incredibly exciting thing. Whenever we get a result of that importance, many scientists, myself included, get frightened. What if this is not right? What if this is wrong? We've got to go back and repeat it or somebody else can repeat it for us. But there was an awful lot of excitement surrounding that because it opened doors to experiments that you could really now - important hypotheses such as the Birkitt lymphoma one-answer using a mammalian system. ${ }^{22}$

The paper announcing the mouse model describes the modification of 13 strains of mice using four different artificial constructions in which a mouse mammary tumor virus promoter (MMTV) had been fused to various segments of a normal mouse $c$ $m y c$ gene. The insertion of these fusion genes into mice was an attempt to simulate the translocation of the oncogene observed in cases of Burkitt lymphoma. Two of the 13 mice developed mammary adenocarcinomas in early pregnancy. In one of these, the progeny that inherited the fusion gene also developed mammary adenocarcinomas during their second and third pregnancies. As a research tool these mice could be used to investigate levels of oncogene expression in tumour formation and how this might be influenced by the chromosomal location of the gene. The mice could also be used to test tumour-inducing and tumour-preventing agents and to provide a source of cancer cells for research. ${ }^{23}$

Oncomouse was purposefully designed using genetic manipulation techniques to develop cancer and to be a research tool for use in a laboratory setting. At the same time, oncomouse was a natural animal: a mouse that needed to be housed, fed, and cared for, and which had the capacity to suffer, to feel pain and when threatened to react as an animal interested in its own survival. ${ }^{24}$ However as a research tool, it is the laboratory life of the mouse that takes precedence, and practices of care become adjunct to and supportive of this way of being mouse.

Lynch has described what he regards as a transformation from naturalistic animal to analytic animal in his observations of researchers experimenting with rats in a neuroscience laboratory. In Lynch's case, researchers engaged in rituals of killing that they referred to as "sacrifice" that enabled them to reduce the holistic animal to its component parts: to cells, brain, and neurons. He argues that the "naturalistic animal" 
is an entity of the "commonsense life world", that of our ordinary perception within everyday life: "a living being, a subject for-itself as well as in-itself" ${ }^{25}$ in a relation with humans such as that between pet and owner and the reciprocity this entails of understanding and emotional attachment. ${ }^{26}$ Laboratory practices transform rats from "holistic" and "naturalistic" creatures into "analytic objects of technical investigation". ${ }^{27}$ Lynch's argument posits different points of view of the animal that are contradictory, and the process by which one view becomes dominant. However, when he talks about the rat as an analytic animal he describes a "product of work", "ostensibly and artifact", "shaped by human agency" and "a product of human intervention". ${ }^{28}$ It is this work that I want to draw attention to, because in the case of the oncomouse it brings mouse as research tool into being, not I would argue, as Lynch suggests, through the transformation of the naturalistic animal, but through juxtaposing natural animal and research tool in ways that overlap and depend upon one another.

The laboratory practices undertaken by Leder and his colleagues result in a series of contingent separations and connections that perform mouse as research tool. The oncomouse is an animal that suffers, it feels pain, and reacts in ways that show it is interested in its own survival. At the same time it is connected to humans as its animal body is modified to develop cancer and produce tumor cells analogous to those produced in the human body. Its mice offspring help to construct lines of inheritance along which cancer-causing genes travel. In the course of scientific problem-solving and ethical oversight, the mouse becomes both a natural animal that is analogous to a human animal and a research tool for scientific problem-solving. The mouse's suffering is set in relation to the suffering of humans with cancer and justified by the magnitude of the problem it is designed to solve and the potential alleviation of human suffering this could achieve. Leder said it came as a shock to him that people would not immediately see the advantage in using mice in this way:

It never really occurred to me that if what you want to do is alleviate human suffering, particularly a disease like cancer for which there is so much pain involved, that anybody could possibly see this as a wrong.

This relation between human and animal suffering is a risk/benefit calculation that makes tolerable the mouse that suffers by connecting it to human suffering and the value of oncomouse as research tool in the alleviation of that suffering. The mouse is made to function seamlessly as both natural animal and research tool: it is made to cohere.

\section{Oncomouse as invention}

\section{United States}

Leder's research was funded by the pharmaceutical company Du Pont, and as such was part of an emerging trend at the time in industry-funded research. ${ }^{30}$ Leder's contract with Du Pont obliged him to report commercially promising outcomes to the Harvard Office of Technology Licensing and Industry, and Du Pont had priority over the marketing of such products. These university-industry partnerships transformed 
the traditions of gentlemanly science, with its sharing of resources and peer review, into a more competitive and contractual relationship ${ }^{31}$ that in this case propelled the mouse out of the laboratory and into the patent office. As Leder explains:

\begin{abstract}
One of the elements of the creation of these mice - these animal models of human disease - was that it coincided with a time that the Supreme Court had just decided that all life forms could be patented. And as an obedient employee of Harvard Medical School, Tim and I reported this invention to our Office of Technology Licensing as an invention and a discovery, which we disclosed to them and which potentially would be patentable. ${ }^{32}$
\end{abstract}

The decision to which Leder refers is that by the Supreme Court to patent a bacterium. In 1972, the United States Patent and Trademarks Office (USTPO) was asked to determine whether an oil eating bacterium created by Ananda Chakrabarty was an invention. This was the first time the patent office had been asked to consider a living entity as potentially patentable. Its initial rejection of the patent and subsequent appeal by Harvard brought it in June 1980 to the Supreme Court, which held by a very slim margin of 5 to 4 , that the bacterium was not a product of nature but a product of manufacture and therefore deserved a patent. One of the judgements stated that:

Here, by contrast, the patentee has produced a new bacterium with markedly different characteristics from any found in nature, and one having the potential for significant utility. His discovery is not nature's handiwork, but his own; accordingly it is patentable subject matter under $\$ 101 .^{33}$

Harvard filed a patent application on the oncomouse with the USPTO in June 1984, naming as inventors Philip Leder and Timothy Stewart. The abstract describing the invention read as follows:

A transgenic non-human eukaryotic animal whose germ cells and somatic cells contain an activated oncogene sequence introduced into the animal, or an ancestor of the animal, at an embryonic stage.

The application was broad and covered all non-human animals modified in this way.

The very same question that had occupied the attention of the USPTO in 1972 now compelled its attention again. Was the oncomouse nature's handiwork or Leder's? The answer was in part determined by the outcome of another patent application, announced on 7 April 1987, the subject of which was a multicellular polyploidy oyster. The USPTO rejected this application because it lacked a novel step but the oyster was determined to be "patent-eligible subject matter" in keeping with the USPTO's declaration at this time that it considered all "non-naturally occurring, nonhuman multicellular living organisms, including animals, to be patentable subject matter". ${ }^{35}$ This determination had direct implications for Harvard's application and on 12 April 1988, the oncomouse made history as the first animal to be awarded a patent. In what way is a living creature enacted as a product of manufacture and as a 
patentable invention? And how does this enactment of oncomouse sit in relation to other ways of being mouse?

The USPTO defines patentable subject matter as any new and useful process, machine, article of manufacture or composition of matter. ${ }^{36}$ Natural phenomena are not patentable subject matter but inventions can comprise, use, or modify nature, as was the case with Chakrabarty's oil-eating bacterium. With the decision of the USPTO to patent the oncomouse, animals became patent eligible subject matter in the United States. The oncomouse was genetically modified and according to the USPTO was not nature's handiwork but that of Leder and Stewart. Patents give the owner the right to exclude others from using, manufacturing, selling, offering to sell or importing the patented invention for a period of about twenty years. They comprise a mechanism that enables the owner a return on his/her investment and acts as an incentive for further investment. As a patented invention, the oncomouse is performed as a tool that can be sold under licence to scientists interested in understanding, treating and possibly curing cancer and it becomes a source of revenue for its inventors and the patent owner.

With the USPTO's decision, the human made qualities of the oncomouse were given priority. This set the oncomouse apart from its naturally-bred brothers and sisters and opened the way for other animals to be inventions. In the United States, humans are now able to invent animals and thus avail themselves of another avenue through which payment for animal labour and animal products can be transacted. However, there was opposition to this new state of affairs. At hearings in 1987 and 1989, animal rights activists argued that animal patents would degrade animals, environmentalists argued that genetically modified animals might escape and contaminate the environment, clerics argued that patenting reduced God's creatures to material objects, and farmers worried about the economic consequences for small farms. ${ }^{37}$ Opponents attempted to separate out the natural animal as an autonomous moral entity that would be harmed by allowing animals to be patented and thereby disrupt the relation "natural animal-research tool-invention" that the patenting of animals established. However, U.S. patent law contains no basis for the USPTO or courts of law to deny a patent on the basis of morality and the opponents were unsuccessful. As Bagley notes, it is a "de facto system of patenting first, and asking questions later with regard to morally controversial biotech subject matter". ${ }^{38}$ Oncomouse as a moral entity was not the business of the USPTO, and space for it was not opened up elsewhere, as for instance by congress. In the United States it was the connections between the oncomouse's novel physical attributes, its human design and ability to assist with the study and treatment of cancer - all features that made it a new and useful composition of matter - that prevailed. It was with these connections, and their separation from moral concerns, that the decision to award the patent was made. Mouse as "natural animal-research tool-invention" was made to cohere, and a logic of animal patenting was established.

\section{Europe}

In Europe however, two clauses in the patent legislation created a legal and moral space in which natural animal as an autonomous moral entity could be made present: Article 53(b) prohibited the patenting of plant and animal varieties, and Article 53(a) 
prohibited patents on inventions that were contrary to public morality (an ordre public). ${ }^{39}$ Harvard's patent application was initially rejected by the European Patent Office (EPO) on grounds that the oncomouse was an animal variety and therefore the patent was prohibited under Article 53(b). Additionally, the patent office ruled that it could not be assumed that the modification in mice could be extended to all other animals (Article 83 EPC). Harvard appealed this decision and the Board of Appeal ruled in Harvard's favour, stating that Article 53(b) applies to some but not all animals and that "in the absence of serious doubts substantiated by verifiable facts" there was no reason to refuse the patent under Article $83 .{ }^{40}$ However, the board expressed the view that in the case of a genetically manipulated animal there could be compelling reasons to consider article 53(a), and they remitted the case to the Examining Division of the EPO for further consideration. ${ }^{41}$

Article 53(a) sets the requirements of a patent in relation to questions of morality but leaves open to interpretation the criteria and method of determining whether or not morality is a bar to patenting. The Examining Division chose to employ a "balancing" test:

[T]he question of morality has to be examined and possible detrimental effects and risks have to be weighed and balanced against the merits and advantages aimed at.

It weighed and balanced claimed benefits, such as remedying human disease, against the risk that oncomice might escape into the environment where their genetic modification might be transferred to wild mice, and against the risk of cruelty to animals. The Examining Division determined that the invention would be of benefit in remedying human cancer because genetically modified mice of this sort were unique and there were few suitable alternative models. They conceded that the potential introduction and spread of genetically modified animals into the environment might cause harm, but argued that this risk, and that of animal cruelty, did not present a significant bar to patenting because such matters were best dealt with by laboratory protocols: this shifted questions of morality onto national laws and guidelines that govern the use of animals in scientific research. ${ }^{43}$ With these connections and separations, oncomouse as research tool was deemed useful and of benefit, and any risks of environmental harm and animal suffering were relegated to the laboratory for management: a separate moral space to that of patents. With the apportioning of harm and suffering as matters for laboratory protocols, the utility of the invention alone became a matter for the patent office. The Examining Division concluded that the invention could not be considered "immoral or contrary to public order" and the patent should not be denied. ${ }^{44}$

The patent was granted by the EPO on 13 May 1992. However, between 18 December 1992 and 13 February 1993, seventeen oppositions were filed against this decision. The Opposition Division of the EPO commenced opposition proceedings that continued until 16 January 2003. At the outset of these proceedings, the Opposition Division rejected as inadmissible all opponents' objections except those put forward under Article 53 (a), those being objections of direct relevance to the decision of the Examining Division. 
Opposition came primarily from animal rights groups across several European countries: from Britain, the British Union for the Abolition of Vivisection (BUAV), and Compassion in World Farming (CWF); from Germany, Bundesverband der Tierversuchsgegner, Evangelischer Stadtkirchenverband Köln, and Deutsches Tierhilfswerk; from Switzerland, Keine Patent auf Leben; and from Austria, Wiener Tierschutsverein. In addition, several German political groups, such as the Ökologisch - Demokratische Partei, Fraktion Bundnis 90/ Die Brunen im Bayer, Bundesland Hessen, submitted appeals, as did a small number of German citizens. ${ }^{45}$ The joint submission from BUAV and CWF, for instance, argued that, if the Examining Division had carefully weighed usefulness and suffering, animal suffering would exceed any benefit. The oncomouse was of limited usefulness when it came to testing such things as anti-cancer drugs, and non-animal alternatives were available. They challenged the breadth of the patent, arguing that it potentially extended animal suffering to all mice and other research animals:

The Opponents believe that most members of the public would reject as immoral the production of a dog or monkey designed to develop cancer. Even if an oncomouse was acceptable to some people, the Opponents have no doubt that most would view an ono-dog or oncochimpanzee as morally unacceptable. ${ }^{46}$

They regarded the alteration of the natural animal's genetic structure as an act that was in itself immoral, and as an offence compounded by the fact that it resulted in suffering. Opponents argued that animal suffering cannot be weighed against human suffering because it is morally repugnant for humans to deliberately cause harm to animals and the ends do not justify the means:

The Opponents believe that it is contrary to morality for humanity to change an animal's genetic structure with the clear purpose of predisposing that animal to suffering.

And as the opening quote showed, they argued it is blasphemous to claim that humans have invented an animal because only God creates life and, even from a secular standpoint, claiming an animal as an invention is at odds with the "modern approach to animals" that regards them "not as existing simply for our use and profit, but as our fellow creatures - capable like us, of feeling pain and suffering". ${ }^{47}$ For the BUAV and CWF the oncomouse was "designed to suffer and die" and no human should condone such deliberate harm. These opponents used 53(a) to argue for an autonomous moral entity: an animal that has rights and needs of its own that would be denied if an animal were to be genetically modified and become an invention. Patents, they contended, were "the very antithesis of a caring relationship" because they allowed "the patent holder to exploit the patented animal". ${ }^{48}$ The offence is the disruption of the natural animal as a consequence of its deliberate genetic modification: an offence exacerbated by allowing the patent. Opponents did not accept the connections and separations between mouse as natural animal, research tool and invention that made mouse as patentable entity acceptable. Nor did they accept that matters of morality would be adequately managed within the laboratory. They viewed the very act of 
genetic modification as violating the mouse's moral autonomy and integrity and laboratory protocols that permitted such modification as morally unacceptable.

The Opposition Division ruled against the opponents and upheld the separation of moral concerns and utility established by the Examining Division. Accordingly the patent was maintained, but in an amended form that applied to rodents only. This restriction was a concession by Harvard made on 24 April 1997 to narrow the scope of their claim to rodents. ${ }^{49}$ Opposition continued however and caused further delays as the patent office duly conducted public hearings. The final settlement was announced on 6 July 2004 and it was to uphold the patent as granted, being applicable to rodents only. ${ }^{50}$ In Europe the oncomouse and its onco-rodent brothers and sisters became inventions more than twenty years after the priority date of the patent, which was 22 June $1984^{51}$ : a symbolic victory perhaps but nevertheless one that established the relation "natural animal-research tool-invention" and the logic of animal patenting that accompanied this and that set the precedent for other rodents, at least, to become patented inventions.

\section{Canada}

In 1985, Harvard University applied for a Canadian Patent on the oncomouse and other transgenic non-human eukaryotic animals whose germ cells and somatic cells contain an activated oncogene sequence introduced into the animal, or an ancestor of the animal, at an embryonic stage. In Canada, as in the United States and Europe, there was opposition to animal patenting from religious, environmental and animal rights groups such as: The Canadian Council of Churches and Evangelical Fellowship of Canada; the Canadian Environmental Law Association; Greenpeace Canada; the Canadian Association of Physicians for the Environment; Sierra Club; International Fund for Animal Welfare; and Animal Alliance of Canada. ${ }^{52}$ However, as in the United States, the Canadian Patent Act does not include an 'ordre public' limitation ${ }^{53}$ that would allow moral concerns to be considered as possible grounds for the denial of a patent. Instead, the deliberations of the Canadian Patent Office on Harvard's application focused on the extent to which the oncomouse satisfied the definition of invention in the Canadian Patent Act. The Canadian definition of "invention" is very similar to that in the United States Act. It is:

Any new and useful art, process, machine, manufacture or composition of matter, or any new and useful improvement in any art, process, machine, manufacture or composition of matter. ${ }^{54}$

And in Canada, as in the United States, bacteria have been patentable since $1982 .{ }^{55}$ However, the question as to whether higher life forms should be patentable was considered by the Canadian Patent Commissioner to be "more debatable" and a distinction was thus made between the patentability of lower and higher life forms.

The initial ruling by the Patent Examiner, in June 1993, denied the patent on the oncomouse as being outside the definition of invention. A further decision, in 1995, allowed claims to the process, the cells and plasma containing the oncogene and method for making the mouse, but not the mouse itself. The Commissioner held that an invention being a 'manufacture or composition of matter' was something the 
inventor could control, and on this point he separated the gene construct from its animal host. The gene construct, the $M M T V / m y c$ fusion gene, was made externally to the body of the mouse and was therefore a composition of matter made by human hands. The mouse, by comparison, had been gestated in utero and was the work of nature: it was therefore nature and not man that made the final product. Harvard challenged this separation of the work of humans and nature in an appeal to the trial division of the Federal Court. The appeal was dismissed. The trial judge's decision hinged on two points: reproducibility, and the distinction between human control and the work of nature:

The mouse is a complex life form and many of its features are not under the control of the inventors.... A mouse is not "raw material' which was given new qualities by the inventor.... The creation of the oncomouse is a marriage between nature and human intervention. What is involved here is the insertion of the myc gene and subsequent breeding... the result of the gestation process is infinitely variable and, in its detail, unknown. ${ }^{56}$

This lack of control meant that the claimed invention was not reproducible and therefore not patentable subject matter. However, the outcome of a subsequent appeal reversed this decision and awarded the patent. The appeal court ruled that "The oncomouse is both unobvious and a new and useful 'composition of matter'; therefore it is an 'invention' within the meaning of section 2 of the Act". ${ }^{57}$ The ruling was that the patent Act was silent on the patentability of non-human animals and therefore did not exclude such organisms. The oncomouse was a combination of human ingenuity and laws of nature but would not exist in nature. It required human ingenuity to bring it into being and was therefore appropriately a composition of matter.

However, the opponents, mentioned earlier, sought to intervene and the Supreme Court granted them appeal standing so that they could challenge the patent. ${ }^{58}$ In the Supreme Court, judges were asked to rule on a single question: was the oncomouse a "manufacture" or "composition of matter" and therefore an invention? The Court, with a 5 to 4 majority, upheld the view of the Patent Commissioner that an invention, being a "manufacture" or "composition of matter", was something the inventor could control and that the gene construct fell into this category, being made externally to the body of the mouse, but that the mouse had been gestated in utero and was therefore a product of nature. As Justice Bastarache, writing for the majority concluded:

The body of a mouse is composed of various ingredients or substances but it does not consist of ingredients or substances that have been combined or mixed together by a person. Thus I am not satisfied that the phrase "composition of matter" includes a higher life form whose genetic code has been altered in this manner. ${ }^{59}$

Bastarache and his colleagues were of the view that only Parliament was in a position to respond to concerns associated with patenting higher life forms and to amend the Patent Act. ${ }^{60}$ Whereas the dissenting minority argued that even though inventions such as genetically modified animals had not been anticipated at the time that the Patent Act was drafted, they should be considered inventions in the same way other 
unanticipated inventions have been: such things as moon rockets, antibiotics, telephones and email. They proposed that Canada, with intellectual property legislation similar to that of the United States and other countries that have granted the patent, should arrive at a similar outcome. ${ }^{61}$

The majority decision of the Canadian Supreme Court upheld certain connections and separations made by previous rulings in the case. For instance, single-cell organisms were separated from multicellular ones, and only the former could be inventions. Human handiwork was connected to the gene construct but separated from the gestation of the mouse in utero and its birth. Human control and reproducibility were connected to the gene construct but not to the mouse. These connections and separations did not establish a relation "natural animal-research tool-invention" and there was no accompanying logic of animal patenting to set the precedent for other animals to be patented in Canada. The matter of animal patenting was deferred to the parliament. ${ }^{62}$ In 2002, the Parliament's Canadian Biotechnology Advisory Committee recommended that the Canadian Patent Act be amended to allow the patenting of higher life forms. However, the Parliament has been slow to act and, at the time of writing, had not adopted this recommendation. ${ }^{63}$

\section{Conclusion}

In Canada, Europe and the United States, separations and connections were made between enactments of mouse as natural animal, research tool and invention that resulted in a different outcome in each jurisdiction. In the United States, technical questions were separated from moral ones and connections were made between the oncomouse and other patent-eligible subject matter. The oncomouse was a product of human ingenuity that was new and useful, and questions of morality were not the business of the patent office. In Europe, concerns about animal welfare and risks to the environment were separated from judgements about the invention's utility. Welfare concerns, such as animal cruelty and the risk of gene flow to wild mice, were matters to be dealt with by laboratory protocols. Questions of benefit and the utility of the invention were matters for the patent office. In Canada, the oncomouse's gestation in utero was connected to nature and not to human control. Oncomouse could be natural animal and research tool but not a new and useful art, process, machine, manufacture or composition of matter. Only the gene construct was connected to bacteria and other patentable entities.

For the oncomouse to become an invention it needed to be enacted as natural animal, research tool and invention in ways that overlapped and depended on one another: in ways that cohered. In other words, it needed to be integrated into a seamless and coherent logic of utility and human control. In each jurisdiction, opponents attempted to disrupt this logic by focusing on moral concerns. Opponents positioned themselves as guardians of an autonomous moral subject - the natural animal. However, decisions made by divisions within patent offices and courts of law separated out moral concerns as not relevant to the question of animal patenting in each case. If there was a battle to be fought on moral grounds, it was to be fought elsewhere, in the laboratory or in the parliament, but not in the patent office. This separation enabled utility to prevail as the defining enactment of oncomouse as invention, and that 
determined whether or not the relation mouse as natural animal-research toolinvention would cohere enough to award the patent. In the United States and Europe this relation prevailed; in Canada it did not. In Canada, the connections and separations between the oncomouse's autonomous nature and its genetically modified nature, and the extent to which the latter enabled the oncomouse's biology to be under human control and reproducible, became the locus of separation.

To conclude, I want to emphasise that the relationship between humans and animals that animal patenting establishes, and the decisions made about whether animal patenting is right, appropriate, moral or good, are highly contingent upon what the animal and its component parts are set in relation to. In the United States and Europe, opposition to animal patenting failed because morality was separated out as not the business of the patent office, whereas in Canada, opposition won the day, not by winning the moral argument, but because it hinged on the definition of patent-eligible subject matter, which is core business of the patent office and of courts of law charged with determining such matters: it could not be separated out. The issue at stake in Canada was whether and to what extent the definition of patenting and the oncomouse could be connected. The gene construct connected the mouse did not.

Therefore, the question as to whether or not animals should be patented was not a matter resolved with reference to some essential quality of animals or quality of the things patented in the past to which animals were compared. As I have shown, it was answered in practice by the extent to which the oncomouse was set in relation to the practices, processes and deliberations of laboratories, patent offices and courts of law in different jurisdictions. The contingency of enactments of mouse as natural animal, research tool and invention and of the way each enactment overlaps with and depends upon the others, determines the outcome and establishes the logic of patenting, that in the United States and in Europe made animal patenting acceptable, right and good (although not to the same extent), and in Canada did not.

\footnotetext{
${ }^{1}$ School of Philosophy, Anthropology and Social Inquiry, University of Melbourne, Australia rmrobins@unimelb.edu.au

${ }^{2}$ Philip Leder talks with Richard M. Cohen, former CBS News Senior Producer about his life in science. Lasker Luminaries. An Interview with Philip Leder. 2001. http://www.laskerfoundation.org/awards/library/lumin pl.html

${ }^{3}$ British Union for the Abolition of Vivisection and Compassion in World Farming. Oncomouse. Anex 1: Facts and Arguments under rule $55 \mathrm{c}$. Notice of opposition. 11.01.93. Application No. 85304490. Method for producing transgenic animals. European Patent Office, http://www.epoline.org/ ${ }^{4}$ J. Law. 2004. After Method: Mess in Social Science Research. London \& New York; J. Law. Pinboards and Books: Juxtaposing, Learning, and Materiality. In Education and Technology: Critical Perspectives, Possible Futures. David W Kritt and Lucien T. Winegar, eds. Lexington Books.

${ }^{5}$ J. Law. 2002. Aircraft Stories: Decentering the Object in Technoscience. Duke Durham \& London: 4. ${ }^{6}$ Ibid.

${ }^{7}$ B. Latour. 1993. We Have Never Been Modern. Harvard.; J. Law. 2004. After Method: Mess in Social Science Research. London \& New York.

${ }^{8}$ J. Law. Ibid.; A. Mol. 2002. The Body Multiple: Ontology in Medical Practice. Durham NC and London.

${ }^{9}$ A. Mol. 1999. Ontological Politics: A Word and Some Questions. In Actor Network Theory and After. John Law and John Hasards, eds. Oxford and Keele: 74-89.
} 
${ }^{10}$ H. Verran. 2001. Science and an African Logic. Chicago.

${ }^{11}$ H. Rheinberger. 1997. Towards A History of Epistemic Things: Synthesizing Proteins in the Test Tube. Stanford; Latour. op. cit. note 5; B. Latour. 2004. Politics of Nature. Cambridge MA.; K. Knorr Cetina. 1999. Epistemic Cultures. Cambridge MA.; Mol. op. cit. note 6 and note 7; Law. op. cit. note 3. ${ }^{12}$ D. Haraway. 1997.Modest_Witness@Second_Millennium.FemaleMan ${ }^{\odot}{ }_{\text {Meets_OncoMouse }}{ }^{\mathrm{TM}}$. New York and London.

${ }^{13}$ Ibid, p.79

${ }^{14}$ Ibid, p.97

${ }^{15}$ Oncogenes are genes that contribute to the production of cancer.

${ }^{16}$ P. Leder. A New Genesis in Genetics and Medicine. Part II. BioEssays 1984; 1(2): 52-54.

${ }^{17}$ Interview with P. Leder. Harvard Medical School. Boston. 19 October 2007.

${ }^{18}$ Ibid.

${ }^{19}$ Ibid.

${ }^{20}$ In 1984, recombinant DNA technology was new and a focus of scientific and public concerns about its potential biohazards. See S. Krimsky. Genetic Alchemy. Cambridge MA. Recombinant DNA technology is also referred to as genetic manipulation, genetic modification, genetic engineering and gene technology.

21 Ibid.

${ }^{22}$ Ibid.

${ }^{23}$ T. Stewart, P. Pattengale and P. Leder. Spontaneous Mammary Adenocarcinomas in Transgenic Mice that Carry and Express MTV/myc Fusion Genes. Cell October 1984; 38: 627-637.

${ }^{24}$ M. Hauskeller. The Reification of Life. Genomics, Society and Policy 2007; 3(2): 70-81.

${ }^{25}$ M. Lynch. Sacrifice and the Transformation of the Animal Body into a Scientific Object: Laboratory Culture and Ritual Practice in the Neurosciences. Social Studies of Science 1988; 18 (2): 268

${ }^{26}$ Ibid.

${ }^{27}$ Ibid, p. 266

${ }^{28}$ Ibid, p. 269

${ }^{29}$ Op. cit. note 13

${ }^{30}$ S. Krimsky. 1991. Biotechnics \& Society: the Rise of Industrial Genetics. New York.

${ }^{31}$ Ibid.

${ }^{32}$ Lasker Luminaries. An interview with Philip Leder. At

http://www.emfoley.com/luminaries/nirenberg/timeline.shtml (last accessed 16 April 2008)

${ }^{33}$ Diamond v Chakrabarty 447 U.S. 303. 1980. http://supreme.justia.com/us/447/303/case.html (last accessed 1 July 2008)

${ }^{34}$ US Patent \#4,736,866. At http://patft.uspto.gov/netacgi/nph-

Parser?Sect $1=$ PTO $\&$ Sect $2=$ HITOFF $\& d=$ PALL $\& p=1 \& u=\% 2$ Fnetahtml $\% 2$ FPTO $\% 2$ Fsrchnum.htm $\& \mathrm{r}$ $=1 \& \mathrm{f}=\mathrm{G} \& \mathrm{l}=50 \& \mathrm{~s} 1=4736866 . \mathrm{PN} . \& \mathrm{OS}=\mathrm{PN} / 4736866 \& \mathrm{RS}=\mathrm{PN} / 4736866$ (last accessed 1 July 2008)

${ }^{35}$ M. Bagley. A Global Controversy: The Role of Morality in Biotechnology Patent Law. University of Virginia Law School Public Law and Legal Theory Working Paper Series 2007; paper 57, p. 322. http://law.bepress.com/uvalwps/uva publiclaw/art57 (last accessed 28 March 2008)

${ }^{36}$ United States Code Title 35 Patents. Section 101, which provides that "whosoever invents or discovers any new and useful process, machine, manufacture, or composition of matter, or any new and useful improvement thereof, may obtain a patent ..." http://www.uspto.gov/web/patents/legis.htm (last accessed, 5 May 2008)

${ }^{37}$ D. Kevles. 2002. Of Mice \& Money: the story of the world's first animal patent. Daedalus. 131. Spring. p. 86

${ }^{38}$ Krimsky, op. cit. note 30. p. 318

${ }^{39}$ European Patent Convention. 1973. Chapter 1. Art 53. http://www.epo.org/patents/law/legaltexts/html/epc/1973/e/ma1.html (last accessed 2 July 2008)

${ }^{40}$ European Patent Office. 2005. Notifications of decision. 18.03.2005. Summary of Facts and Submissions. T0315/03.

http://www.epoline.org/portal/public/!ut/p/kcxml/04 Sj9SPykssy0xPLMnMz0vM0Y QjzKLN4i3dAfJ gFjGpvqRqCKOcAFfj zcVKBwpDmQ726kH6LvrR-

gX5AbGlFunK4IAEFiq1o!/delta/base64xml/L01DVE83b0pKN3VhQ1NZS0NsRUEhL29Kb2dBRU1R aENFTVloQ0dJUUlTRkdVWnpDQU1CUUEhLzRCMWljb25RVndHeE9VVG9LNzlZUTdEbUc0Uk EvN18wX0cyLzY2MDA1Ny9vcmdlcG9saW5lcG9ydGFsZnJhbWV3b3JrcG9ydGxldGJhc2VTdGF0Z 
VBvenRsZXRCYXN1QWN0aW9uL29yZy5lcG9saW51LnBvenRhbC5hcHBsaWNhdGlvbnMucmVna XN0ZXJwbHVzLnBvcnRsZXQuUlBBY3Rpb25EaXNwbGF5TWFpbg (last accessed 2 July 2008)

${ }^{41}$ Bagley, op. cit. note 30, p. 331

${ }^{42}$ Ibid.

${ }^{43}$ Ibid. European Directive 86/609/EEC on the protection of animals used for experimental and other scientific purposes was adopted to harmonize practices in the area of animal experimentation and has been implemented to varying degrees at the national level: for instance, the Animals (Scientific Procedures) Act 1986 (UK). http://eur-

lex.europa.eu/smartapi/cgi/sga_doc?smartapi!celexapi!prod!CELEXnumdoc\&lg=EN\&numdoc=31986 L0609\&model=guichett (last accessed 26 November 2008)

${ }^{44}$ Ibid.

${ }^{45}$ Bagley, op. cit. note 35. p. 1

${ }^{46}$ Ibid, p. 7

${ }^{47}$ British Union for the Abolition of Vivisection and Compassion in World Farming, op. cit. note 3

${ }^{48}$ Ibid.

${ }^{49}$ Bagley, op. cit. note 35 . p. 5

${ }^{50}$ Ibid.

${ }^{51}$ A priority date is established for an invention when the applicant first files a patent application that describes the invention in detail. This is used to determine if the invention is new. If the invention is known to the public before this date it cannot be awarded a patent.

http://www.ipaustralia.gov.au/resources/glossary.shtml (last accessed 2 July 2008)

${ }^{52}$ The Canadian Bar Association. 2003. The Harvard Mouse Case: Developments in the Patentability of Life Forms. http://www.cba.org/cba/newsletters/ip-2003/ip2.aspx (last accessed 26 November 2008)

${ }^{53}$ M. Swenarchuk. 2003. The Harvard Mouse and All That: Life Patents in Canada. Canadian Environmental Law Association. Toronto. p.19. http://cela.ca/celacourts/detail.shtml?x=1319 (last accessed 2 July 2007)

${ }^{54}$ Canadian Patent Act, R.S.C. 1985, c.P-4, s.2. http://laws.justice.gc.ca/en/showdoc/cs/P-4/boga:s_2//en\#anchorbo-ga:s_2 (last accessed 2 July 2008)

${ }_{55}$ This was the year in which Canada approved the patenting of the Chakrabarty bacterium.

${ }^{56}$ President and Fellows of Harvard College v Commissioner of Patents (T.D.), 1998, 3 F.C. 510. http://reports.fja.gc.ca/eng/1998/1998fc22348.html/1998fc22348.html.html (last accessed 2 July 2008) ${ }^{57}$ President and Fellows of Harvard College v Commissioner of Patents (C.A.), 2000, 4 F.C. 528. http://reports.fja.gc.ca/eng/2000/2000fc27094.html/2000fc27094.html.html (last accessed 2 July 2008)

${ }^{58}$ These were:The Canadian Council of Churches and the Evangelical Fellowship of Canada; Canadian Environmental Law Association, Greenpeace Canada, Canadian Association of Physicians for the Environment, Action group on Erosion Technology and concentration and the Canadian Institute for Environmental Law and Policy; Sierra Club of Canada; and Animal Alliance of Canada, International Fund for Animal Welfare, Inc. and Zoocheck Canada Inc.

${ }^{59}$ Harvard College v. Canada (Commissioner of Patents) [2002] 4 S.C.R. 45. 2002 SCC 76: 162. p. 90. http://csc.lexum.umontreal.ca/en/2002/2002scc76/2002scc76.html (last accessed 2 July 2008)

${ }^{60}$ This matter was considered by the Canadian Biotechnology Advisory Committee and resulted in the publication of the following report: Canadian Biotechnology Advisory Committee. 2002. Patenting of Higher Life Forms: Report to the Government of Canada, Biotechnology Ministerial Coordinating Committee. Ottawa, Canada.

${ }^{61}$ Op. cit. note 43, and note 11. p. 23

${ }^{62}$ Swenarchuk, op. cit. note 53

${ }^{63}$ Op. cit. note 55; M. Rimmer. 2008. Intellectual Property and Biotechnology. Glos \& Massachusetts. 